\title{
Feasibility and competitiveness of intensive smallholder dairy farming in Brazil in comparison with soya and sugarcane: Case study of the Balde Cheio Programme
}

\author{
André Monteiro Novo ${ }^{\mathrm{a}, *}$, Maja Slingerland ${ }^{\mathrm{b}, 1}$, Kees Jansen ${ }^{\mathrm{c}, 2}$, Argyris Kanellopoulos ${ }^{\mathrm{d}, 3}$, Ken E. Giller ${ }^{\mathrm{e}, 4}$

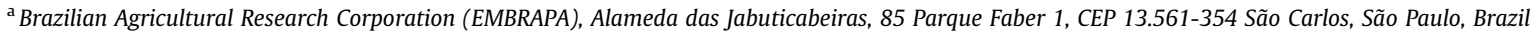 \\ ${ }^{\mathrm{b}}$ Plant Production Systems, Wageningen University, Radix-West, Building 107 Room W3.Aa.083, Droevendaalsesteeg 1, 6708 PB Wageningen, The Netherlands \\ ${ }^{c}$ Knowledge, Innovation and Technology Group, Hollandseweg 1, 6706 KN Wageningen, The Netherlands \\ ${ }^{\mathrm{d}}$ Plant Production Systems, Wageningen University, Radix-West, Building 107 Room W3.Cd.103, Droevendaalsesteeg 1, 6708 PB Wageningen, The Netherlands \\ e Plant Production Systems, Wageningen University, Radix-West, Building 107 Room W3.Fa.103, Droevendaalsesteeg 1, 6708 PB Wageningen, The Netherlands
}

\section{A R T I C L E I N F O}

\section{Article history:}

Received 16 March 2012

Received in revised form 16 May 2013

Accepted 20 June 2013

Available online 26 July 2013

\section{Keywords:}

Intensification

Smallholder farming

Sugarcane

Soybean

Land use

\begin{abstract}
A B S T R A C T
Technology introduction and the intensive use of resources, particularly in smallholder farming systems, are at the core of debates about future food security and sustainable livelihoods. In Brazil, land use changes promoted by competing agricultural chains require a search for alternative modes of production for family farms. We analyse the technical and economic viability of intensification of dairy farming by smallholders in the "Balde Cheio" (Full Bucket) programme. On average, family farmers who joined the programme increased milk production three-fold whereas at regional level there was a significant reduction of $8 \%$ between 2003 and 2009. Comprehensive datasets from São Paulo state and four other regions across Brazil were collated and analysed to explore for whom, how and when intensive dairy production is a feasible option. Data envelopment analysis allowed us to compare inefficiencies among farms and highlight different strategies for technological changes. The empirical evidences in this study indicate the technical viability of the more intense use of resources towards family-based dairy farming systems. Higher productivity was due to a combination of more lactating cows/area (31\%), higher productivity/cow (24\%), better labour performance (37\%) while using less land area ( $-7 \%)$. The gross margin/area almost doubled although milk prices had increased by only $7 \%$. The economic outcome of the intensified systems was on average $\mathrm{R} \$ 3000 /$ ha which was competitive with $\mathrm{R} \$ 600 /$ ha for sugarcane leasing and $\mathrm{R} \$ 700 /$ ha for soybean production. Despite the smaller returns on land, large landowners can have a good household income with sugarcane or soybean, but for smallholders the intensification of dairy is the only option. Compared with the alternative of wage jobs in urban areas, we found it very competitive for 40 out of 50 farmers in the sample in terms of income per family member involved in the production process.
\end{abstract}

(c) 2013 Elsevier Ltd. All rights reserved.

\section{Introduction}

Brazil is at the core of the debate concerning the global future supplies of food, fibre and fuel. The country is the world's leading producer of agricultural commodities such as sugar, ethanol, soybean, coffee, oranges, poultry and beef. Brazil is currently also fifth in the world in dairy products (FAO, 2011), with more than half of

\footnotetext{
* Corresponding author. Tel.: +55 (0) 16 34115687, mobile: +55 1681177185 .

E-mail addresses: andre.novo@embrapa.br (A.M. Novo), maja.slingerland@ wur.nl (M. Slingerland), Kees.Jansen@wur.nl (K. Jansen), argyris.kanellopoulos@ wur.nl (A. Kanellopoulos), ken.giller@wur.nl (K.E. Giller).

1 Tel.: +31317 483512/483077.

2 Tel.: +31317 484097; fax: +31317485616.

3 Tel.: +31317483512/487220.

4 Tel.: +31317 483512/485812
}

the production value generated by one million small family-based farms (Neves and Consoli, 2006). The close relationship between milk production and family-run enterprises is due to multifaceted characteristics of dairy farming, such as the regular monthly income, immediate cashflow, availability of both labour and large areas of grasslands. Furthermore, investment in land and cattle were a preferred means to accumulate capital in the past (Hecht, 1993). For many decades, particularly during earlier periods of uncontrolled inflation, extensive, low input livestock farming based on trade of calves and sale of surplus milk was the safest option to protect capital. Since the economy was stabilised in 1994 , the provision of income became the main issue rather than reducing risk. Increasing competition for land for other uses, such as sugarcane for ethanol in the South-east region of Brazil and soybean expansion throughout the Cerrado region, has re-shaped the farming landscape of Brazil. 
Within this context of stronger competition for resources, more intensive modes of farming may provide alternative pathways to better livelihoods. A significant literature highlights the potential of milk production for the intensification of small-scale farming worldwide (FAO, 2010; Herrero et al., 2010; MacDermott et al., 2010; Udo et al., 2011). Nonetheless, a wide array of potential threats can restrict the development of dairy production to small households and several studies foresaw a large reduction in the number of family dairy farms (Farina, 2002; Bennett et al., 2006; Gonçalves et al., 2010). Poor resource use efficiency at farm level (Gomes, 2006; Gomes and Ferreira Filho, 2007) makes dairy less competitive, particularly when located in regions with soaring opportunity costs. Furthermore, competition for land is not the sole issue to be addressed. Shifts in technology, such as the introduction of ultra-high temperature (UHT) milk treatment in the 1990s, allowed expansion of milk production at huge distances from urban centres where it was not earlier possible (Novo et al., 2010). Strong and sustained governmental support for other agricultural commodities, the growing economy of the countryside cities, as well as the fuzzy labour laws influence investments by small- and medium-scale dairy farmers who depended upon milk production for their livelihood (Novo et al., 2012).

Notwithstanding the huge favourable market for milk, with potential buyers distributed across the whole country, and availability of credit (Nunes, 2007), sustainable milk production is not easy for family-based farmers to realise. The lack of governmental policies and limited access to knowledge are partially responsible for the relative stagnation in productivity of the dairy chain (Martins, 2002). From a historical perspective, Novo et al. (2010) stressed the inadequacy of the technological "package" during the 1970s (strong focus on breeds, buildings and machinery) for small-scale family farmers who had little success with use of such an "exogenous" model of dairy farming. As a result, intensification of milk production was broadly regarded as an expensive option that would invariably lead farmers to bankruptcy (Faria and Silva, 1996). Most credit facilities still promote the idea that merely buying cows and collective bulk tanks would be sufficient to allow dairy production to soar. Such approaches did not accomplish their objectives, neither increasing productivity nor generating income for smallholder farmers, as reflected by the nearly stable performance of this sector over time (Tupy et al., 2005). On the other hand, there is substantial evidence that intensification of dairy production could enhance productivity and potentially boost net incomes at farm level (Esteves et al., 2003; Tupy et al., 2003; Camargo et al., 2006; Primavesi et al., 2005).

In this paper we explore the intensification process within small dairy farms in terms of technical viability and the potential to generate gains in income. In addition, we compare the economic outcome of the more intense way of farming with the opportunity costs of other competing agricultural chains (particularly leasing of land for sugarcane and soybean production), as well as the alternative to quit farming and seek a wage job in the surrounding cities. We base our analysis on the "Balde Cheio" (BCP) or "full bucket" programme, an initiative of Embrapa South East Livestock Division that aimed to develop and adapt production processes and administrative tools for small dairy farmers and extension service technicians. The programme began in 1999 in two municipalities in the states of São Paulo and Minas Gerais with a small number of farmers, but a combination of factors attracted the interest of farmers from other regions. First, the high productivity and income at farm level despite the context of small areas and restricted availability of capital for investment. Second the approach of experimentation with "new" technologies at local level underpinned the confidence of different actors who cooperated to develop incremental solutions to local problems. Finally a broad range of institutional arrangements at different levels created conditions for the
Balde Cheio Programme to become very popular: in 2012, there were 388 different partnerships with governmental extension services, dairy cooperatives, farmers' unions, NGO's and other funding agencies. The number of farmers assisted rose from 400 in 2010 to more than 3000 in 2012, in 483 municipalities spread widely across the country (Camargo, 2012, personal communication).

\section{The integrative technology introduction during the Balde Cheio Programme}

The low intensity of the production processes is still a strong characteristic among family dairy farmers in Brazil. The main indicators of productivity and efficiency remain low, similarly to 40 years ago (Faria and Martins, 2008). In this research, we analyse the intensification process of small dairy farmers who had such an extensive way of production at the start of the programme. Farmers in the sample used on average an area of 16.4 ha $(N=58$ varying from 1 to 75.1 ha) for dairy production which represented 93\% of the total area of the farm. The productive system was based on continuous grazing of degraded pastures (Brachiaria brizantha, $B$. decumbens and Paspalum spp.) complemented with chopped fodder (napier-grass) and seasonal use of concentrates. The use of natural breeding was predominant $(72 \%)$ mostly on non-specialised cows (no-defined breed 60\%, crossbred Zebu x Holstein, 28\%, Holstein $7 \%$ and beef cows $3 \%$ ), milked by hand (65\%), once or twice a day (43 and 57\% respectively). A remarkable feature is the herd structure composed with only $42 \%$ of cows and $30 \%$ of lactating cows whereas growing heifers and male calves complete the rest of the herd. With such characteristics, farmers assisted by the programme did not differ from the average pattern of family dairy farmers as observed in a previous study (Novo et al., 2012).

Despite the similarities between assisted farmers such as relatively small area, family labour force, and small contribution of external revenues, a closer look exposes the large complexity within this group, with significant differences regarding herd composition, capital availability, size of the family, soil fertility, and the proximity to the urban areas, among others. All these factors together will shape how and when each farmer will respond to the intensification process preconised by the programme. Similarly, different combinations of practices and intensity of resource use are needed to address the limitations and advantages of every local situation at farm level.

In the technology domain, the Balde Cheio Programme proposes a comprehensive and adapted set of production processes and administrative tools to attain better production and resource use efficiency. Some of the key technologies are: (a) rotational grazing of pasture (tropical species), which involves soil fertility management with annual soil analysis, application of lime, use of chemical and organic fertilizers, erosion control followed by a division in small paddocks with electric fences; (b) the gradual introduction of more productive species of grasses such as varieties of Panicum maximum (cv. Tanzânia or Mombaça) and Cynondon dactilon cv. Tifton 85 among others suited to the soil fertility, the fodder planning, the production level of the herd and agro-ecological characteristics of each farm (c) the use of chopped whole sugarcane to supplement fodder supply whenever the climate conditions limits pasture productivity; (d) simple administrative tools such as basic record keeping of financial and technical data, such as calving and breeding dates, individual monthly milk production of cows and the reproductive calendar to support herd management; (e) pasture irrigation and over-seeding of tropical grasses with oat and ryegrass; (f) gradual introduction of improved breeds of dairy cows (increasing the proportion of specialised breeds in the herd) accordingly with the level of the farm management; $(\mathrm{g})$ other complementary practices such as the use of by-products as 
concentrates (e.g. cotton seeds, citrus pulp, soybean hull) aiming to balance the diet when the quality of the fodder is not enough to support the nutritional demand from the herd, vaccination schemes, culling of unhealthy animals, the restoration of natural vegetation on the margin of rivers and streams, provision of sufficient shade during the day and grazing during the night, among others.

Some other features of the intensification process can be highlighted. First, the introduction of a set of well-known technologies, as described above, instead of cutting-edge new technologies. Second, the rhythm and the sequence of the introduction of each "new" component are fundamental to achieve good results in terms of productivity and economic indexes (Novo, 2012). For instance, it makes no sense to improve the cattle breed nor to increase the proportion of milking cows in the herd when there is not sufficient quality feed available. The third characteristic is the continuous adaptation of technologies and processes to the diversity found amongst dairy farmers and their agro-ecological conditions in a similar approach as suggested by Bernard et al (2011) in the same country. In essence, the "Balde Cheio" programme manipulates simultaneously many production factors, according to the local situation, step by step, resulting in more fodder per farm, with better quality, higher production/cow, reduction of the labour load, better reproductive indexes, longer lactating period/cow and modification of the herd structure aiming at proportionally more cows than heifers and calves.

\section{Materials and methods}

Two different datasets of farmers from the Balde Cheio Programme were studied to evaluate agro-technological options may help to address expected strong competition for resources in the future. First, we analysed the existing data of all farmers in São Paulo State who joined the first phase of the programme (105 farmers dispersed across 21 sub-regions). The dataset was complemented by field visits and telephone calls to explore the households' profiles and the starting technology level. Most variables were available, such as milk volume, average size of the area available to dairy production, entry date, family and hired labour, off-farm revenues, farm inventory (amount of capital invested in cattle, machinery, buildings, fences and others) and technology use at the starting point. To use technological level as an indicator (Table 1), twenty nine different technological processes were identified and received a score and weight accordingly with the intensity of each practice, that comprised a final index of productive processes and the technology use within every farm. From the interviews, milk volume after the $\mathrm{BCP}$ and rate of production change were available for a sample of 58 farmers. National statistics were used to relate the local trends in terms of milk volume with farmers' performance. A principal components analysis (PCA) (Mardia et al., 1979) was used to explore the relationships among all variables available in the initial questionnaire from the programme.

Secondly, a detailed dataset of economic data and technical indexes from 50 farmers with at least 3 years of record keeping was studied. Of these farms, 23 were visited in person, and further data collection from all farmers that remained in the BCP was done by extension service technicians. We chose a 3-year threshold to assess gradual changes over time. Within this sample, farmers entered the programme at different times between 2002 and 2008, so we compared the first and third year that the farmer participated in the BCP, instead of calendar years, to examine the impact of the programme at farm level. Moreover, the influence of seasonal climatic variations on performance of milk production is not as important as when dealing with annual crops. Distribution of farmers over different agro-ecological zones (Fig. 1) allowed us to explore the diversity of dairy farming systems in five regions throughout Brazil.

The large heterogeneity of dairy farming systems rely on a complex combination of production factors and social aspects that result in distinctive allocation of resources. Therefore, we analysed the productivity and the technical efficiency of dairy farmers from the second dataset using Data Envelopment Analysis (DEA) and the input oriented Banker-Charnes-Cooper (BCC) model, which accounts for variable returns to scale (Cooper et al., 2007). The capacity of each individual farm to convert multiple inputs such as labour, capital, land, into outputs (e.g. milk) is compared to the capacity of all other farms to convert the same inputs into outputs. The technically efficient farms ("best" farm practices) are identified and a frontier of technical efficiency is calculated. A farm is characterised as technical efficient when the level of any output cannot be increased without decreasing the level of other outputs or increasing the level of inputs, and the level of inputs cannot decrease without increasing the level of other inputs or decreasing the level of outputs. The distance of each individual farm from the frontier is interpreted as a score of technical efficiency (Cooper et al., 2004). Results of DEA provide information on decisions that could be made by currently inefficient farms to become efficient. The simple case where one input is used to produce one output can be illustrated graphically (Kanellopoulos et al., 2012). However, in cases where multiple inputs and outputs are involved in the production process, a graphical representation of DEA is not possible and linear programming models are used (Cooper et al., 2007).

To account for variation in decision making between years, for each individual farm, we averaged the last 3 years data on input and output levels. The inputs included in the DEA models are: land size (ha), labour availability (hours), operational costs (R\$) and number of cows (heads) while the outputs are milk production (litres) and herd sales (R\$).

\section{Results and discussion}

The outcomes of the first data set (Table 1), describe the profile of farmers who joined the Balde Cheio Programme. The results in terms of land tenure ( $92 \%$ had the possession of the land), labour characteristics (almost half of the farmers depend exclusively upon family labour and another one quarter had hired sporadic labour) and average size of the land (less than 20 ha) define the features of family farmers in the sample. Furthermore, only one-third of the households earned off-farm income with less than one minimum salary on average, which represents a small contribution to their livelihood.

Remarkably, the weak productivity at the starting point of the $\mathrm{BCP}$ did not reflect the technological level of production. Despite several agro-technical processes being implemented before farmers joined the programme (T1), they were seldom applied efficiently or effectively. In many cases, capital was mostly used to invest in cattle, buildings and machinery alongside with fundamental restrictions to productivity such as lack of fodder, poor soil fertility and problems of animal health issues. This resulted in poor productivity of around $2500 \mathrm{l} / \mathrm{ha}$ /year, not far above the average national index of $1800 \mathrm{l} / \mathrm{ha}$ /year (IBGE, 2010). The difference between these two indexes results from São Paulo being the wealthiest state in the country, offering high opportunity costs with expensive land. As a result, extensive grazing systems are not found as frequently in São Paulo state as in the frontier regions in the North and North West of the country. During the intensification process, milk volume per farm rose sharply but the large standard deviation indicates huge differences in technical performance. One farmer in the sample decreased his production volume, six 
Table 1

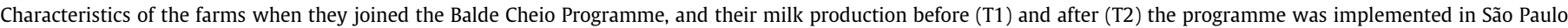
state from 2003 to 2009 ( $n=58)$.

\begin{tabular}{|c|c|c|c|c|c|c|c|c|}
\hline & $\begin{array}{l}\text { Area dairy }{ }^{\mathrm{a}} \\
\text { (ha) }\end{array}$ & $\begin{array}{l}\text { Off-farm income ( } R \$ / \\
\text { year) }\end{array}$ & $\begin{array}{l}\text { Family labour } \\
\text { (Person) }\end{array}$ & $\begin{array}{l}\text { Hired labour (Days/ } \\
\text { year) }\end{array}$ & $\begin{array}{l}\text { Inventory } \\
\text { (R\$) }\end{array}$ & $\begin{array}{l}\text { Technological } \\
\text { level }^{\mathrm{c}}\end{array}$ & $\begin{array}{l}\text { Milk (T1) (l/ } \\
\text { day) }\end{array}$ & $\begin{array}{l}\text { Milk }(\mathrm{T} 2)^{\mathrm{d}}(\mathrm{l} / \\
\text { day })\end{array}$ \\
\hline Mean & 16.4 & 1703 & 2.6 & 54 & 107,431 & 21.7 & 113 & 260 \\
\hline SD & 15.5 & 4476 & 1.4 & 86 & 75,162 & 11.2 & 89 & 220 \\
\hline Minimum & 1 & 0 & 0 & 0 & 1400 & 3 & 8 & 30 \\
\hline Maximum & 75.1 & 24,950 & 6 & 400 & 406,800 & 50 & 520 & 1400 \\
\hline
\end{tabular}

a Area destined to dairy farming necessary to produce the whole fodder to all categories (pastures for lactating and dry cows, heifers, calves and bulls, including the area to sugarcane, silage and napier grass) as well as other areas such as shade, corridors, pre-calving paddocks and buildings.

b Capital invested in dairy, without land values.

c Index of productive processes and technologies applied at farm level at the moment of the first visit, before the intervention. The main practices that set up the index were the presence of technical book keeping (BK) and economic accountancy (EA), pasture management (PM), weight criteria to breed heifers (WC), system to feed calves (FC) and number of milking per day (NM); milking place (MP) and irrigation systems (IR); breeding system (BR), milking system (MS) and milk-cooling at farm level (CO). Each

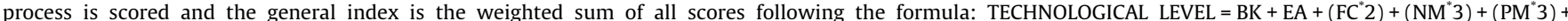
$\left(\mathrm{IR}^{*} 4\right)+\left(\mathrm{MP}^{*} 4\right)+\left(\mathrm{MS}^{*} 5\right)+\left(\mathrm{CO}^{*} 5\right)+\left(\mathrm{MS}^{*} 5\right)$

d Time frame between T1 and T2 is variable depending the entry date of each farmer.

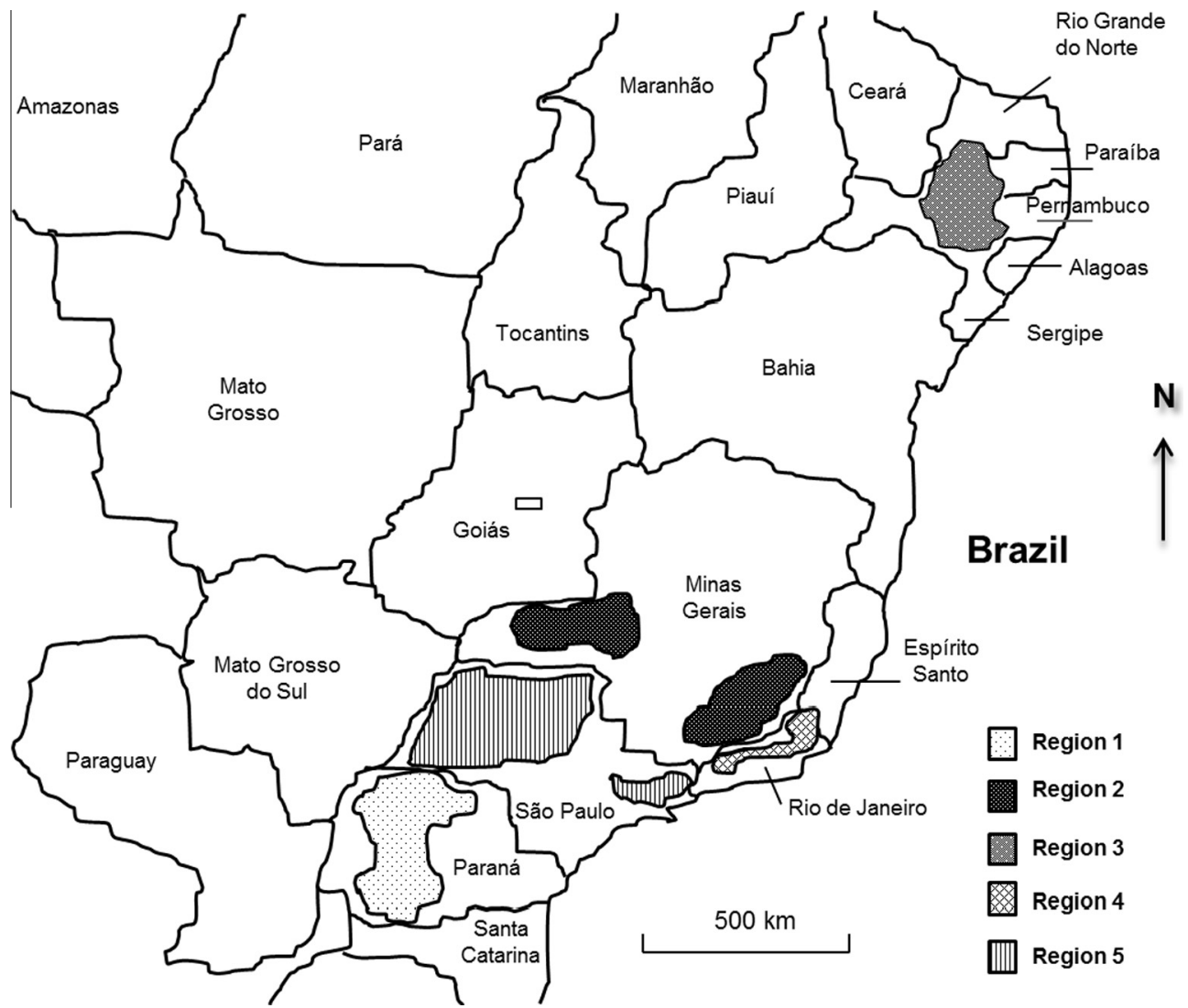

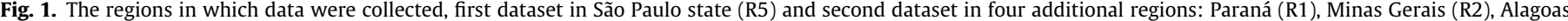
(R3) and Rio de Janeiro (R4)

others maintained their milk production but the majority produced two to six times more milk (Fig. 2).

Thus production increased substantially, on average more than three-fold, particularly when compared with the trend of local dairy production in São Paulo state where milk production decreased 8\% between 2003 and 2009. The competition for land, mainly for sugarcane production, and labour due to the growing urban economy and unclear labour laws, explain the general lack of development of milk production in São Paulo state (Novo et al., 2012 unpublished). Notwithstanding, increasing milk volume may not be the only criteria to evaluate intensification. Looking closer to the seven farmers who reduced or maintained stable production after the BCP started, we found two interesting cases of land intensification. One farm produced the same volume of milk with less land and diversified activities on the farm by leasing land for sugarcane, and producing beans and coffee. Another farmer took advantage of new technologies (such as the rotational grazing instead of harvesting fodder daily) to reduce by half his labour requirements rather than increase productivity.

We used principal components analysis instead of a simple matrix of correlation to examine relationships between the 10 variables measured (Fig. 3) but in a reduced dimension. All variables available in the initial questionnaire on T1 were considered. The first two principal components together explained $43 \%$ of the total variation within the dataset.

The PCA (Fig. 3) reveals the following relationships between the variables. Firstly, farmers who join the programme had generally a poor level of technology. This is one of the objectives of BCP that 


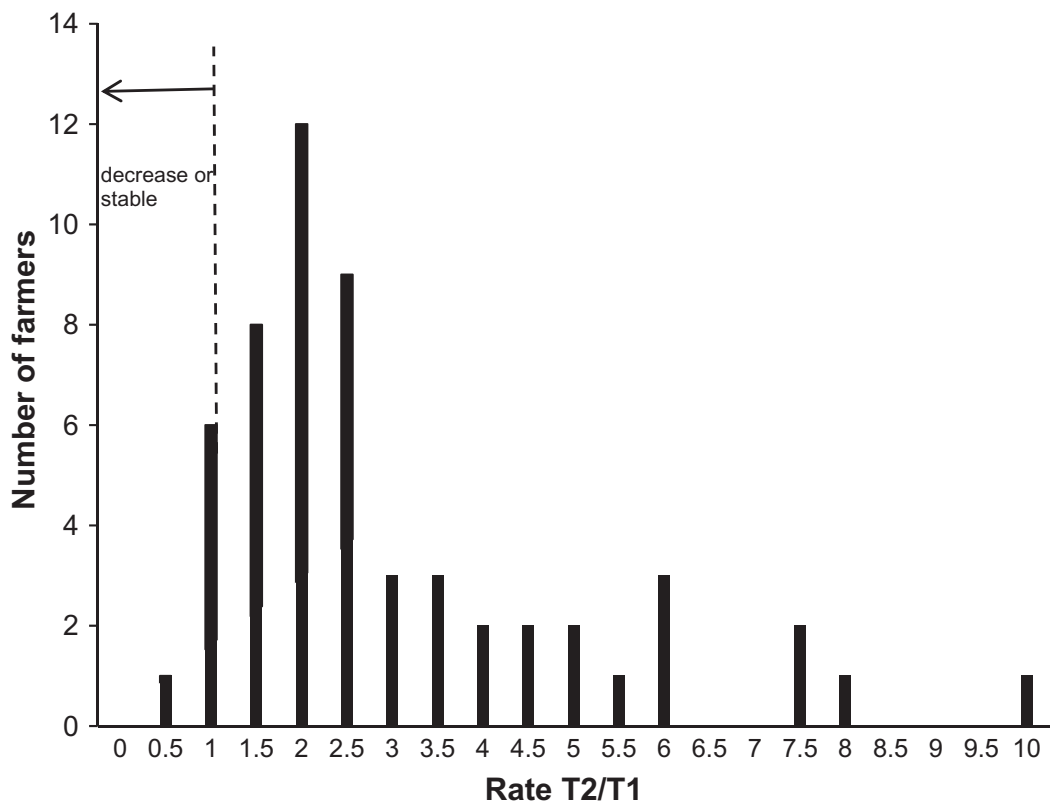

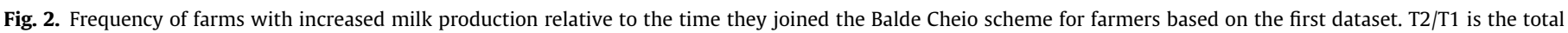
amount of milk produced in a year after the intensification process (T2) divided by the average of milk volume produced in the first year of the programme (T1).

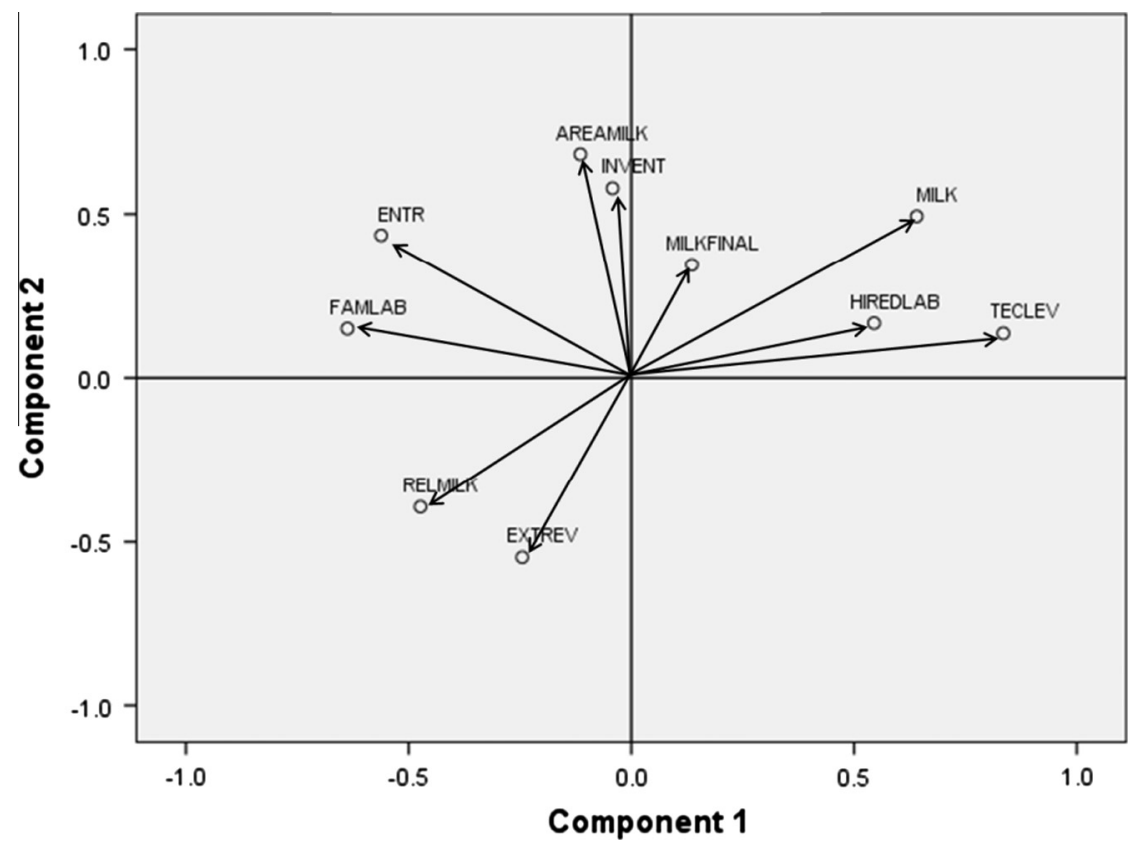

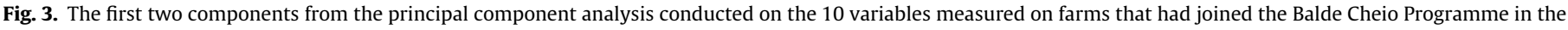

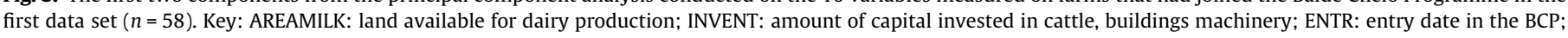

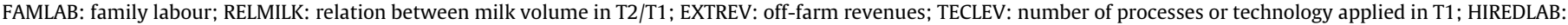
amount of hired labour; MILK: milk volume produced on entry into the BCP T1; MILKFINAL: milk volume produced at the end of the measurement period T2.

gives preference to small-scale family farmers to initiate the intensification process rather than to wealthier farmers. Secondly, there is strong positive correlation among hired labour, technology level and milk volume at the starting point, which highlights a subgroup of slightly wealthier farmers. However, this sub-group did not increase production more than average after intensification. This can be explained because poor farmers started off by applying less technology, so that introduction of new technology gave outstanding results. Thirdly, the households with higher off-farm income produced less milk initially, presumably as they had less need to rely on milk production. On the other hand there was a strong correlation between the rate of increase in milk volume and off-farm revenue. This may reflect the ability of farmers with offfarm income to intensify production rapidly and benefit earlier from intensification. Finally, the amount of capital invested was not significantly linked with technology level at entry into the scheme (T1) but was correlated with bigger herds and buildings respectively 0.67 and $0.90(P<0.01)$. To summarise, small size and family-based farmers with low initial level of technology achieved the greatest increases in milk volume, and good improvements in efficiency and 
Table 2

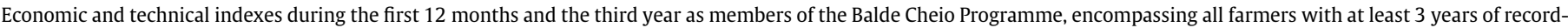
keeping in five regions $(n=50)$.

\begin{tabular}{|c|c|c|c|c|c|c|c|c|}
\hline & $\begin{array}{l}\text { Area } \\
\text { dairy } \\
\text { (ha) }\end{array}$ & $\begin{array}{l}\text { Gross margin/area }^{a} \\
\text { (R\$/ha/year) }\end{array}$ & $\begin{array}{l}\text { Milk } \\
\text { price }^{a} \\
(\mathrm{R} \$ / \mathrm{l})\end{array}$ & $\begin{array}{l}\text { Lactating cows/area }{ }^{\mathrm{b}, \mathrm{c}} \\
\text { (lact. cows/ha) }\end{array}$ & $\begin{array}{l}\text { Milk } \\
\text { volume } \\
\text { (1/day) }\end{array}$ & $\begin{array}{l}\text { Productivity/cow } \\
\text { (1/cow/day) }\end{array}$ & $\begin{array}{l}\text { Labour productivity } \\
\text { (1/man/day) }\end{array}$ & $\begin{array}{l}\text { Land productivity } \\
\text { (1/ha/year) }\end{array}$ \\
\hline First year & 20.4 & 1700 & 0.621 & 1.39 & 216 & 7.88 & 117 & 5635 \\
\hline Std. error & 2.5 & 256 & 0.01 & 0.14 & 30 & 0.55 & 12 & 601 \\
\hline Third year & 19 & 3273 & 0.664 & 1.83 & 309 & 9.79 & 160 & 8655 \\
\hline Std. error & 2.9 & 441 & 0.01 & 0.16 & 37 & 0.47 & 13.3 & 745 \\
\hline$T$ & -0.96 & 5.33 & 3.42 & 4.05 & 7.41 & 6.93 & 4.36 & 7.13 \\
\hline$P(2$-tail $)$ & 0.342 & 0 & 0.001 & 0 & 0 & 0 & 0 & 0 \\
\hline $\begin{array}{l}\text { Ratio of third } \\
\text { year/first year }\end{array}$ & 0.93 & 1.92 & 1.07 & 1.31 & 1.43 & 1.24 & 1.37 & 1.54 \\
\hline
\end{tabular}

a Deflated prices accordingly INPC index (IBGE, 2010). The gross margin is the sum of all revenues from the dairy activity (milk, cheese, animals, manure) minus operational costs (direct expenses with fertilizers, concentrates, labour, vaccines, electricity, taxes) divided by the area destined to dairy activity. Fixed costs, such as depreciations, the owner' salary, the opportunity costs over capital, among others were not considered in the calculation. In $2008,1.00 \mathrm{US} \$=\mathrm{R} \$ 1.84$ (SD = 0.27 ) and in $2010 \mathrm{R} \$ 1.76$ $(\mathrm{SD}=0.05)$.

b This index indicates fodder availability within the farm (number of heads per area), the reproductive efficiency (conception rate), the lactating period of the cow (the rate lactating/dry cows) and the herd distribution (number of cows in relation to the whole herd). It is calculated by the average number of lactating cows/month divided by the total area destined to dairy in that period. This specific index aims to get a comprehensive view of the overall performance of all these factors simultaneously.

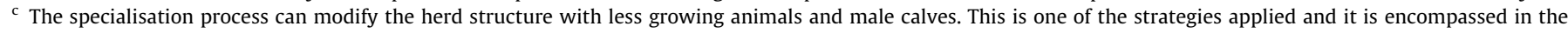
index of lactating cows/ha.

competitiveness were also observed for those households who were slightly wealthier at the beginning.

The combined evaluation of farmers' profiles and the interactions among variables collected from the initial questionnaire gave insight as to for whom the programme benefited the most and the average situation after intensification in São Paulo state. However, as it did not provide detailed information concerning either the technical or the economic performance, the reasons for success of the intensification process were limited. Therefore, we collated and analysed another dataset from farmers beyond the boundaries of São Paulo state who also joined the programme and had detailed records (Table 2 ).

Almost all measured variables were significantly different after 3 years when compared with the starting situation which confirms that the intensification of the BCP caused deep and far-reaching changes in these dairy systems. Considering all regions, the land area used for milk production did not change significantly, although when we examine each region separately we observe different results which are discussed further case by case below. The gross margin was selected as the main economic indicator in order to get a clear point of view regarding the way farmers take decisions. This index almost doubled although milk prices increased only $7 \%$ in real terms. This was due to a combination of gains in different indicators such as more milk produced (43\%), using less area (7\%), underpinned by more lactating cows per unit area (31\%), higher productivity per cow (24\%), and resulting better performance of labour (37\%). The higher income was supported through gains in productivity and not by higher prices of raw milk. This is also reinforced by the relative stable prices of inputs during the observed period and the small share of herd sales to the total income of the farms. Labour productivity increased not only by gains in milk volume/farm and productivity/cow but also by the introduction of milking machines and shifts in the production system (rotational grazing and irrigation reduced the drudgery of daily harvesting and chopping fodder). Positive gains in the number of lactating cows/area may be understood as an incremental combination of efficiencies in several processes related to milk production. This index represents the final outcome of investments in fodder production, nutrition, reproduction, longer milking period and herd distribution.

Data from all of the farms, irrespective of region, were subjected to data envelopment analysis to compare efficiencies (as output/ input relationships) among different farmers with different strategies or restrictions taking into account the multiple input-output relationships involved in dairy production (Fig. 4). Results of DEA indicates that 27 out of 50 farmers in the dataset were technical efficient whereas, the other 23 farms, theoretically can produce the same level of outputs with lower levels of inputs. Both efficient and inefficient farmers were dispersed across all regions, which suggest that regional bio-physical constraints were not the key issue in achieving technical efficiency. In cases where the regions differ substantially in terms of bio-physical and socio-economic conditions (e.g. soils, climate, access to markets), the comparison of farms that are located in different regions is not possible. Hence, to check the effect of region specific constraints on the level of technical efficiency, we used additional DEA model runs to compare the technical efficiency of each farm with the technical efficiency of all other farms that are located in the same region. This additional DEA model runs were used for region 1 and 2 where enough farms were available. We found the same trend of inefficiencies which implies that the potential effect of one specific region over farmers' performance does not affect the final results.

Considering the inefficient farmers and the full set of parameters we found that incremental reductions in the number of cows

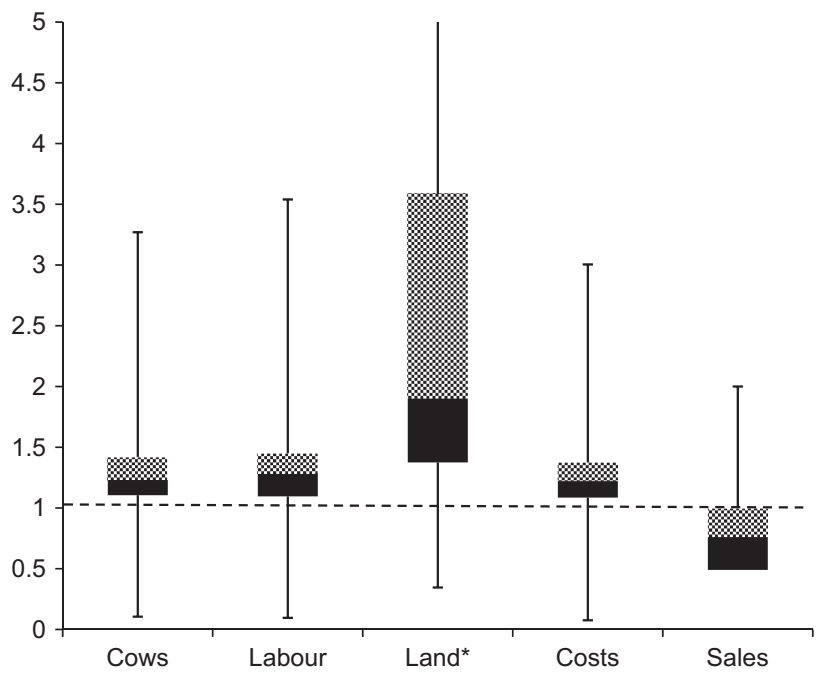

Fig. 4. The relative distance to the frontier derived using the development envelope analysis considering the 23 inefficient farmers and the studied dimensions (see text for further explanation). "A large standard deviation reaching a relative distance of 12 was found for the variable Land. 
(-29\%), labour use $(-34 \%)$ and operational costs (-26\%) and an increase in sales (32\%) would improve the technical efficiency of the evaluated dairy systems. Notwithstanding, land productivity is the key issue when compared with the performance of the efficient farmers. On average, farmers could use one third of the land to produce the same amount of milk. Based on this conclusion, we examine further how land productivity has evolved over time (Fig. 5).

The shallow slope of the curve up to the 24th measurement period (36 months in the BCP) for all farmers, indicates that there is a gradual introduction of practices and a slow learning process that leads to step-wise changes in production factors. For instance, investments in soil fertility take some time to be observed in productivity indices. There is also a gap between changes in cropping practices at farm level (such as better fodder production, higher quality of forage, good practices in ambience and health) and the outcome in terms of shorter calving intervals or higher milk productivity/cow. Furthermore, after building up the infrastructure of the activity, farmers felt more confident to take loans, investing in herd improvements (replacement with specialised dairy breed cows or simply more cows), in irrigation systems or even reducing the area used for dairy leading to direct results. Agro-ecological limitations (such as soil fertility, lack of water for irrigation) or even (more plausibly) labour availability probably become the main reasons to the relative stabilization of the production after the 43rd observation. However, at regional scale we observed quite distinct results deviating from these average trends. Different drivers strongly influenced the rate of change, the adoption of technology and the final outcome in terms of farmers' performance. Some particular strategies illustrated by five farmers were selected and the performance plotted in terms of productivity/area (Fig. 6). It explores the average way of production accordingly to their environment and local context that configures different resource use allocations. All trends occurred in all regions but some strategies were more frequent in certain sites and we are going to explore this variation and complexity.

The trajectory of Farmer 1 matches the trend of Region 1: a steady increase and with no abrupt variation in the process over time. The presence of sufficient infrastructure and labour availability within the family provide the conditions to grow in such a way. Other characteristics of Region 1 are the more regular distribution of rainfall, higher initial soil fertility and better genetic composition of the dairy herd. Social aspects such as the Italian and Germanic background with women doing the milking and less attraction to urban areas are also relevant in explaining labour

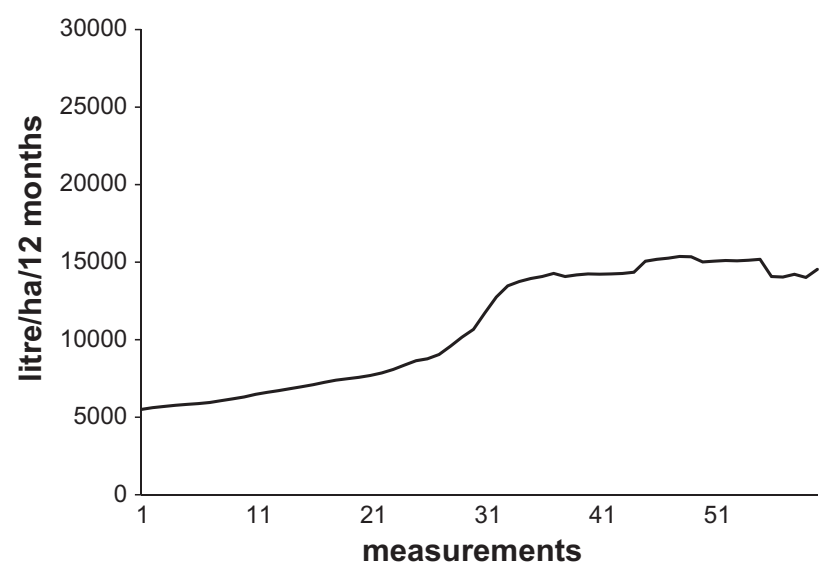

Fig. 5. Dynamic comparison of land productivity (expressed as a rolling mean where each measurement corresponds to 12 months of record keeping, such as from January to December and February to January) considering all farmers and all regions of the second dataset from the Balde Cheio Programme $(n=50)$.

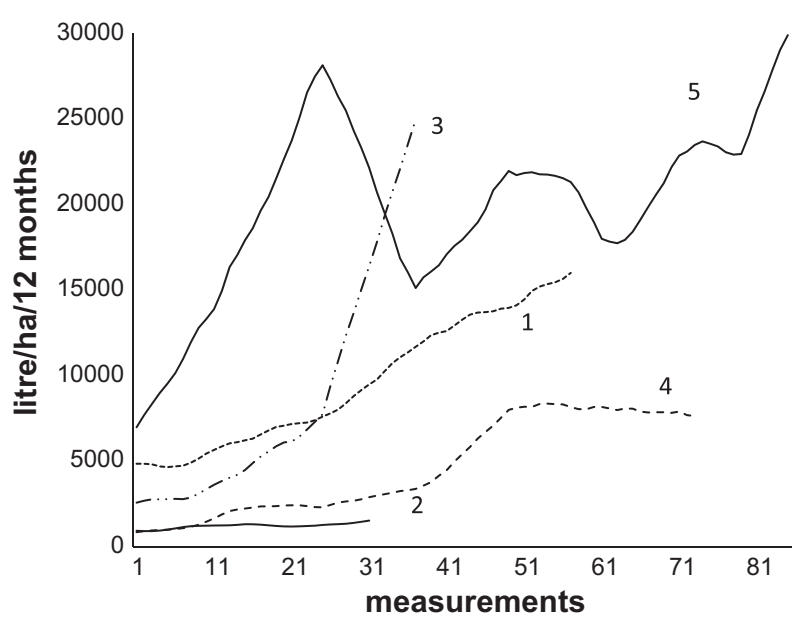

Fig. 6. Dynamic comparison of land productivity considering only specific dairy farmers within the Balde Cheio Programme and strategies depending on the local context.

availability within this region. Farmer 2 is an example of a distinct strategy, where there is no significant change in productivity over time, despite the introduction of technology. This trend was often observed in Region 2 where the farms had large areas (2.2 times above average), crossbred cattle and the absence of other alternative land uses (low opportunity cost), hence keeping the herd focused on beef production still makes sense in economic terms. Farmer 3 on the other hand represents the high potential of the Northeast region (semi-arid conditions and fertile soils) where the introduction of irrigation and cows with higher dairy genetic merits simultaneously trigger rapid increases in productivity after the 20th observation. In this region there was a significant reduction $(-41 \%)$ in the land area allocated to dairy with increasing production. In Region 4, this particular trajectory was selected mainly due a particular combination of events that expose the complexity of technology introduction and the final outcome in productivity indexes at farm level. Until the third year in the BCP, the performance of this farm was modest with a slow increase in production which was motivated by the lack of a reliable milk market and limited access to inputs. However, institutional arrangements with a farmerś organisation and a dairy industry led to the donation of a cooling tank helping the farmer to overcome these limitations. The productivity increased sharply until the 51st measurement when another restriction arose as his family moved to the city reducing labour availability. The situation of Farmer 5 in Region 5 was again different, showing an impressive rate of increasing productivity and large variations in trajectory. The fluctuations are explained by the intense herd trade, variations in the available area for dairy (first inheritance of more land and later the introduction of another activity) which is a common tendency in Region 5. In summary, a complex interplay of factors at regional level such as agro-ecological characteristics (e.g. rainfall distribution, landscape and soil fertility) and opportunity costs (from other competing agricultural chains), inputs and output prices, intertwined with local features such as the size of the farm, labour availability and institutional arrangements to define the rhythm of technology introduction, how and when each farmer applied more or less techniques to increase productivity.

\subsection{The potential production frontier and environmental sustainability}

Based on the farmers' performance in the sample, we highlight some considerations as to the potential of milk production for 
smallholders in the tropics. First, land productivity (on average $8600 \mathrm{~kg} /$ ha/year) was equivalent - or even higher when considering the best farmers - with those observed in developed countries that employ more intense, sophisticated and highly specialised production systems (Milkpoint, 2010). Particularly on farms that reached very high productivity per area (over $15,000 \mathrm{~kg} / \mathrm{ha} / \mathrm{year}$ ) this was achieved through a large number of lactating cows/area (4.8 lactating cows/ha), as a result of strategies that explore the high potential of dry matter production of tropical grasses, and not through achieving extremely high productivity per cow which is a typical strategy of non-grazing systems. On these farms productivity per cow was only $4100 \mathrm{~kg} / \mathrm{lactation}$. Secondly, no single revolutionary technique was responsible for the farmers' performance, but rather a combination of key factors shapes the potential for milk production in Brazil. In essence, it is not sufficient to produce huge amounts of fodder without a balanced herd distribution (cows/heifers and males), attention to health problems, good reproductive indexes and long lactating period because all these variables impact on the number of lactating cows/area, the key variable to obtaining good performance in this particular case. Third, it is remarkable that these outstanding results were obtained by means of a set of agro-technical and managerial processes that cannot be considered as innovations or novelties. The rotational system of grazing for tropical grasses (identified in the 1970s), the use of sugarcane as the main fodder during the dry season (from the 1960s) and the reproductive wheel (from the 1980s) are some examples. The application of basic concepts of herd comfort, rules of animal health care and simple accountancy procedures cannot be seen as an "innovative" way of dairy farming. Fourthly, the evidence for good results across different regions and within the two datasets demonstrates that, in this study, the agro-ecological characteristics were not particularly relevant to achieving high productivity. The way farmers allocate their resources (management) and the strength of the institutional support were more decisive in achieving good technical and economic performance. For instance, well balanced investments in a more intense way of dairy production make it possible to use less land to produce more milk creating room for diversification of land use, economic resilience and greater resource use efficiency.

On the other hand, achieving a high level of productivity and efficiency takes time in such an intensification process. There was a clear time lag from the starting point before a good level of performance was obtained. This occurred after a steady learning process and gradual introduction of different practices after the second or third year of the intensification process. In many cases, farmers do not have enough time to wait for the outcomes and may quit dairy farming (or farming at all) seeking for alternative sources of income. Another key issue is the weakness of local institutional support that can be a constraint to the development at farm level. In some regions the lack of commitment from the regional extension service team was highlighted by farmers as the fragile point of the whole process of change.

The intensification process proposed by the Balde Cheio Programme raises questions about the potential impact on natural resources and broader issues of environmental sustainability. Rodrigues et al. (2006) analysed the BCP impacts in the north-east of São Paulo state using an hierarchical method (AMBITEC-agro) to derive environmental performance indicators of the technology introduction from field measurements. Beyond better production performance indexes, they concluded for 5 farms that the BCP reduced drudgery, increased the environmental consciousness of farmers and reduced negative environmental impacts. Furthermore, the introduction of the BCP practices on an organic dairy farm in São Paulo state (Farmer 44 in our study), with good productivity after 3 years, indicates an interesting path to be explored towards intense grazing systems with less inputs (no chemical fertilizers, using less concentrates and absence of antibiotics).

\subsection{The competitiveness of intensive dairy farming}

Intensified dairy within the BCP gave significant increases in farm income, but whether this is competitive with other options within and beyond the farm gate remains to be seen. We addressed this question by comparing the average performance of dairy farmers in terms of gross margin/area with alternative local competing livelihood pursuits at the regional scale. We selected the most relevant agricultural chains that impact land allocation in Brazil, soybean and sugarcane, addressing different possible prices and production levels and then compared with the gross margin/area obtained from dairy production, both before and after intensification (Fig. 7). First we took the average annual payment per hectare of the sugarcane industry for leasing land in 21 sub-regions in São Paulo state that varied from R\$ 260 to R\$ 660/ha in less favourable regions (hilly landscapes or low fertility soils and fewer sugarcane mills in the surrounding areas) and from $R \$ 460$ to $R \$ 1300 /$ ha in the best regions during the sampled years (IEA-CATI, 2011). Secondly we compared average soybean production/ha in Paraná state (the traditional state for this crop, which varied from $2322 \mathrm{~kg} / \mathrm{ha}$ to $3130 \mathrm{~kg} / \mathrm{ha}$, limited to only one crop/year) combined with price variation from $R \$ 33$ to $R \$ 49$ per $60 \mathrm{~kg}$ of soy grain at the farm gate (the gross margin was $18 \%$ and $39 \%$ respectively) during the same period (IBGE, 2011 and APROSOJA, 2011). Similarly to other commodities, milk price at farm gate also varies within and between years but variations are small (see for instance price variation in Table 2). Furthermore, the feature of monthly payments may represent less commercialisation risks when compared to a single negotiation of crop production in a low price moment (at harvest, for example).

Milk production generated larger revenues for small farmers than other land use options (Fig. 7). However, labour and capital investments vary substantially between these alternative land uses. A distinguishing feature of dairy production is the continuous daily tasks that claims a much greater labour load than soybean production (Oliveira, 2009). This is a key issue that drives farmers' decisions (Novo et al., 2012). The amount of capital required to produce milk is a further constraint with the need of specific investments in machinery, buildings and animals that can reach

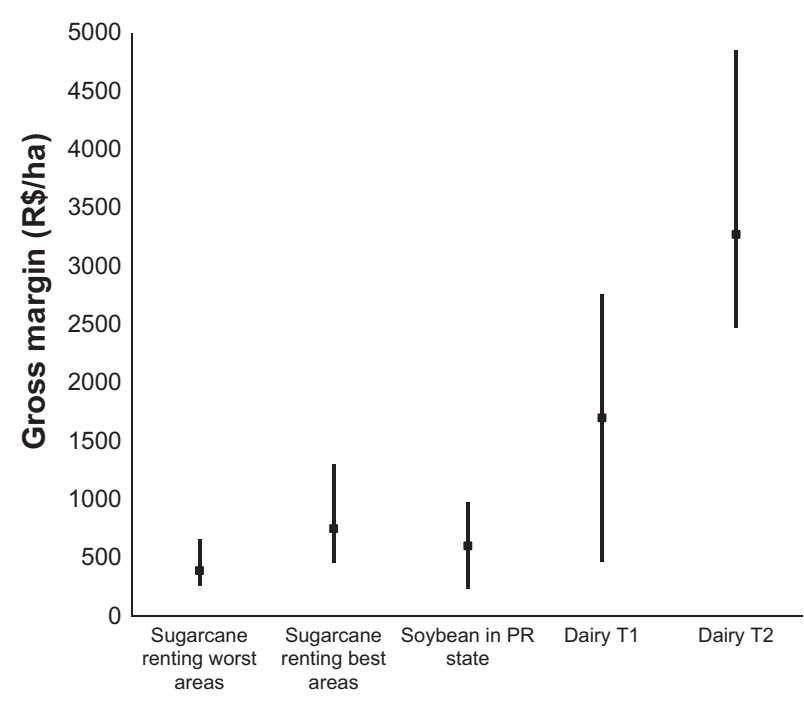

Fig. 7. Gross margin/area ( $\$$ /ha) of competing agricultural chains based on average prices and productivity from 2008 to 2010 


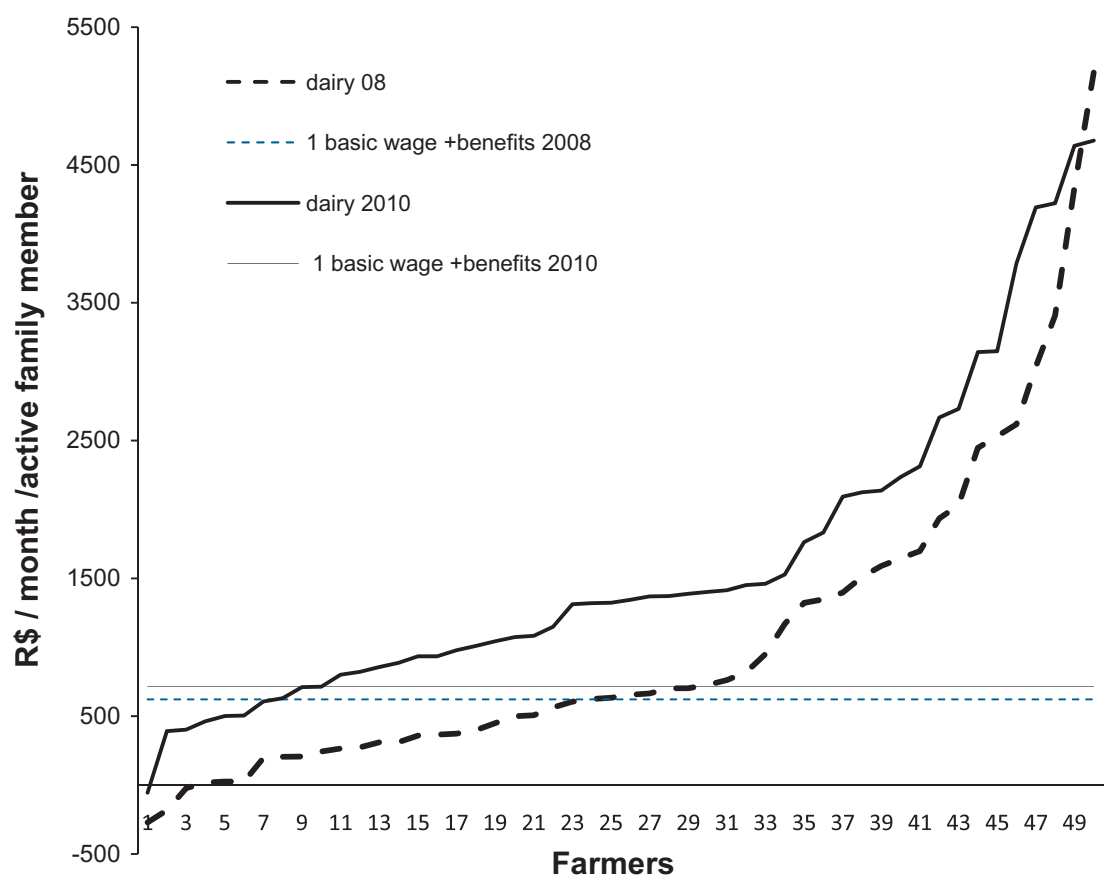

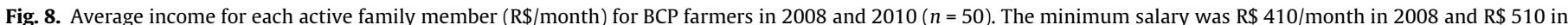
2010 , plus $40 \%$ of benefits (extra salary, vacations and others) (MTE, 2011). In 2008, one US\$ $=$ R $\$ 1.84(S D=0.27)$ and in $2010 \mathrm{R} \$ 1.76(\mathrm{SD}=0.05$ ).

very high values, around $\mathrm{R} \$ 10,730 /$ cow or $\mathrm{R} \$ 21,594 /$ ha $(\mathrm{R} \$$ $1.00=$ US\$ 1.76 in 2010) (de Faria et al., 2010; Camargo, 2011). Whereas using much less labour and capital, soybean requires around 200 ha to obtain economies of scale making modern mechanization (from planting and harvesting) viable.

Beyond the farm gate, when comparing the intense dairy farming with the alternative of urban jobs we took into account the average minimum national wage plus benefits as a threshold value. Considering the low educational level of family members that would move to the cities, the range between one to one and half minimum salary is likely to represent the most common situation (Fig. 8).

In 2008, at least 27 farmers earned less than the minimum salary/ month per each family member involved in the dairy production process. By 2010, after 3 years in the BCP, only 9 farmers earned less than the minimum salary (which in fact rose $24 \%$ in absolute terms). This situation of low wages/person took place in situations of unfavorable rates of family size/ha, specifically in combination with extremely small areas (less than 2 ha) and too many people only partially contributing to the daily activities. In these cases the labour force was not fully occupied with dairy related activities but time was shared with other activities at farm level (poultry, swine, fruits or vegetables production) complementing their livelihood. In both situations (of high profit/person or as a complementing activity into extremely small areas) the intervention increased the revenues of family farmers being an interesting economic alternative to quitting farming and seeking urban jobs.

\section{Conclusions}

The empirical evidences presented by our study of the Balde Cheio Programme indicates that the introduction of technologies for intensive dairy production provides a feasible option for smallholder farmers with average landholdings of 16 ha $(S D=15.5)$. The gradual and balanced investments (mainly provided by a better allocation of resources) through a set of simple but complementary techniques significantly improved farm performance, irrespective of the agro-ecological characteristics at least in the case of the five studied regions of this research. In addition, the high productivity per unit area of land offers an attractive, but knowledge intensive option to smallholders in tropical regions.

Beyond the improved technical performance, this approach to intensification was found to be economically competitive with other land uses and with wage jobs in the city. If farmers have sufficient land to crop soybean or rent out for sugarcane production they may choose these options and have a reasonable household income. However, on average across the 3 years studied, intensive dairy production was an interesting opportunity for most small farmers to add value to local production and create higher income per area and per labour unit.

\section{Acknowledgements}

We thank Embrapa for the funding this research within the Competing Claims on Natural Resources programme in collaboration with Wageningen University. The extension agents Marcelo de Rezende (on behalf of the team from Cooperideal), Walter Ribeiro (on behalf of the FAEMG), Maurício Salles (on behalf of the SENAR/FAERJ); João Bosco, Ciro Gassenferth, Carlos Kauche, Grácia Castellan and Clodoveu Júnior (on behalf of all group from CATI) and Samer Rodrigues (from Pecuária Intensiva) are acknowledged for their key assistance in data collection. We thank the Balde Cheio Programme group (Artur Chinelato, Fernando Mendonça and Marco Bergamaschi) for their essential support and discussions during the field works and Waldomiro Barione for assistance with the data analysis.

\section{References}

APROSOJA, 2011. Brazilian Soy Farmers Realize Best Profits in Three Years. <http:// www.soybeansandcorn.com/news> (accessed 20.01.12).

Bennett, A., Lhoste, F., Crook, J., Phelan, J., 2006. The future of small scale dairying. In: McLead, A. (Ed.), Livestock Report. FAO, Rome, pp. 45-55.

Bernard, J., Le Gal, P.Y., Triomphe, B., Hostiou, N., Moulin, C.H., 2011. Involvement of smallscale dairy farms in an industrial supply chain: when production standards meet farm diversity. Animal 5, 961-971. 
Camargo, A.C., 2011. Viabilidade da produção leiteira na pequena propriedade. In: Pedreira, C.G.S., da Silva, S.C. (Eds.), Anais do Simpósio sobre Manejo de Pastagem. FEALQ, Piracicaba.

Camargo, A.C., Novaes, N.J., Monteiro Novo, A.L., Mendonça, F.C., Manzano, A., Esteves, S.N., Pagani Neto, C., Dias, A.T.F.F., Quibaglia Neto, P., Santos Junior, H.A., Ribeiro, W., Faria, V.P., 2006. Projeto Balde Cheio: Transferência de tecnologia na produção leiteira e estudo de caso do sítio Boa Vista, de Elisário, SP. Comunicado técnico 71. Embrapa, São Carlos.

Cooper, W.W., Seiford, L.M., Zhu, J., 2004. Data envelopment analysis: models and interpretations. In: Cooper, W.W., Seiford, L.M., Zhu, J. (Eds.), Handbook on Data Envelopment Analysis. Kluwer Academic Publisher, Boston, pp. 1-39.

Cooper, W.W., Seiford, L.M., Tone, K., 2007. Data Envelopment Analysis: A Comprehensive Text with Models, Applications, References and DEA-Solver Software. Springer Science + Business Media, Boston, MA, 490pp.

Esteves, S.N., Camargo, A.C., Manzano, A., Novaes, N.J., Freitas, A.R., Tupy, O. Machado, R., 2003. Efeitos de tecnologias agropecuárias em estabelecimentos familiares com produção de leite na região de Muriaé, MG. In: Reunião anual da Sociedade Brasileira de Zootecniam, vol. 40. Anais, Santa Maria.

FAO, 2010. Status and Prospects for Smallholder Milk Production - A Global Perspective. In: Otte, J., Hemme, T. (Eds.). Food and Agriculture Organization of the United Nations, Rome.

FAO, 2011. FAOSTAT: Food and Agricultural Commodities Production; Commodity per Country. <http://faostat.fao.org/site/339/default.aspx>. (accessed 20.12.11).

Faria, V.P., Silva, S.C., 1996. Fatores biológicos determinantes de mudanças na pecuária leiteira. Simpósio Internacional: O futuro dos Sistemas de Produção de Leite no Brasil. Anais, FEALQ, Piracicaba, pp. 77-89.

Faria, V.P., Martins, P.C., 2008. O Desenvolvimento da Pecuária Leiteira no Brasil. In: Albuquerque, A.C., da Silva, A.G. (Eds.), Agricultura Tropical - Quatro Décadas de Inovações Tecnológicas. Institucionais e Políticas, Embrapa, Brasília, pp. 12011231.

Faria, V.P., Camargo, A.C., Novo, A.L.M., de Rezende, M., Cagnin Filho, F., 2010. Balde Cheio em números. Anais do Congresso Panamericano de Gado Leiteiro. FEPALE- Belo Horizonte. CD-ROM,11p.

Farina, E.M.M.Q., 2002. Consolidation, multinationalization and competition in Brazil: impacts on horticulture and dairy products systems. Dev. Policy Rev. 20 (4), 441-457.

Gomes, S.T., 2006. Diagnóstico da pecuária leiteira do Estado de Minas Gerais em 2005: relatório de pesquisa. FAEMG/SEBRAE-MG, Belo Horizonte.

Gomes, A.L., Ferreira Filho, J.B.S., 2007. Economias de escala na produção de leite: uma análise dos Estados de Rondônia, Tocantins e Rio de Janeiro. Revista de Economia Rural 45 (3), 591-619.

Gonçalves, R.M.L., Vieira, W.C., Lima, J.E., Gomes, S.T., 2010. Analysis of technical efficiency of milk-producing farms in Minas Gerais. Econ. Aplicada 12 (2), 321335.

Hecht, S.B., 1993. The logic of livestock and deforestation in Amazonia. BioScience 43 (10), 687-695.

Herrero, M., Thornton, P.K., Notenbaert, A.M., Wood, S., Msangi, S., Freeman, A., Bossio, D., Dixon, J., van de Peters, M., Steeg, J., Lynam, J., Pathasarathy, P., Macmillan, S., Gerard, B., MacDermott, J., Seré, C., Rosegrant, M., 2010. Smart investments in sustainable food production: revisiting mixed crop-livestock systems. Science 327, 822

IEA-CATI, 2011. Instituto de Economia Agrícola-Coordenadoria de Assistência Técnica Integral. Banco de dados, Terra rural, Arrendamento em dinheiro. <http://www.iea.sp.gov.br/out/banco/menu.php> (accessed 18.12.11).

IBGE, 2010. National System of Consumer Price Indexes. Extended National Consumer Price Index - IPCA and National Consumer Price Index - INPC. <www.ibge.gov.br/english/estatistica/indicadores/precos/inpc_ipca/ defaultinpc.shtm> (accessed 30.09.10)
IBGE, 2011. Produção vegetal e rendimento médio lavouras anuais, Estado do Paraná. <http://www.sidra.ibge.gov.br/bda/tabela/listabl.asp? $\mathrm{z}=\mathrm{t} \& 0=24 \& \mathrm{i}=$ $P \& C=932>$ (accessed 20.01.12).

Kanellopoulos, A., Berentsen, P.B.M., van Ittersum, M.K., Oude Lansink, A.G.J.M. 2012. A method to select alternative agricultural activities for future-oriented land use studies. Eur. J. Agron.

MacDermott, J.J., Staal, S.J., Freeman, Herrero M., Van de Steeg, J.A., 2010. Sustaining intensification of smallholder livestock systems in the tropics. Livestock Sci. 130, 95-109.

Mardia, K.V., Kent, J.T., Bibby, J.M., 1979. Multivariate Analysis. Academic Press, London.

Martins, P.M., 2002. Políticas Públicas e mercado deprimem os resultados do sistema agroindustrial do leite. PhD Thesis. Escola Superior de Agricultura Luiz de Queiróz-Universidade de São Paulo, Piracicaba.

Milkpoint, 2010. Estatísticas Lácteas. <www.milkpoint.com.br/mercado> (accessed 17.12.11).

MTE, 2011. Ministério do Trabalho e Emprego. Portal do Trabalho e emprego evolução do salário mínimo; Legislação. <http://carep.mte.gov.br/sal_min/ default.asp> (accessed 20.10.11).

Neves, M.F., Consoli, M.A., 2006. Mapeamento e quantificação da cadeia do leite: relatório final. Projeto PENSA, Workshop do Sistema Agroindustrial do Leite 1 10. <www.fundace.org.br/tomografia.php> (accessed 02.02.12).

Novo, A., Jansen, K., Slingerland, M., Giller, K., 2010. Biofuel, dairy production and beef in Brazil: competing claims on land use in São Paulo state. J. Peasant Stud. 37 (4), 769-792.

Novo, A., Jansen, K., Slingerland, M., 2012. The sugarcane-biofuel expansion and dairy farmers' responses in Brazil. J. Rural Stud. 28 (4), 640-649.

Novo, A., 2012. Islands of Dairy in a Sea of Sugarcane: The Future of Family Dairy Farming in Brazil. PhD Thesis. Wageningen University. ISBN: 978-94-6173-3696 .

Nunes, S., 2007. Instrumentos de política agrícola para a agricultura e a agricultura familiar no Brasil. Conjuntura Agrícola: boletim eletrônico, n.159 (junho) <www.deser.org.br/documentos> (accessed 20.11.11).

Oliveira, W.X., 2009. Análise de índices e indicadores da atividade leiteira: estudo de caso da pecuária leiteira brasileira. Msc Thesis. Instituto Superior de Ciências do Trabalho e da Empresa. Lisboa, Portugal.

Primavesi, O., Camargo, A.C., Monteiro Novo, A.L., 2005. A legislação ambiental e a viabilidade da pequena propriedade de produção de leite utilizando pastagens. Simpósio Nacional e Congresso Latino-Americano de Recuperação de Âreas Degradadas 6, 497.

Rodrigues, G.S., Tupy, O., Camargo, A.C., Monteiro Novo, A.L., Bonadio, L.F., Tokuda, F.S., Andrade, E.F., Shiota, C.M., Silva, R.A., 2006. Avaliação Sócio-Ambiental da Integração Tecnológica Embrapa Pecuária Sudeste para Produção Leiteira na Agricultura Familiar. Agr. São Paulo 53 (2), 35-48.

Tupy, O., Esteves, S.N., Manzano, A., Camargo, A.C., Novaes, N.J., Freitas, A.R. Machado, R., 2003. Ganhos de produtividade na produção de leite de estabelecimentos familiares na região de Muriaé, MG. In: do Congresso Brasileiro de Medicina Veterinária, vol. 29. Anais.

Tupy, O., Yamaguchi, T., Martins, P.C., Carneiro, A.V., 2005. A ineficiência custo da produção de leite no Brasil: XLIII CONGRESSO DA SOBER "Instituições, Eficiência, Gestão e Contratos no Sistema Agroindustrial”, vol. 1. Anais, Ribeirão Preto.

Udo, H.M.J., Aklilu, H.A., Phong, L.T., Bosma, R.H., Budisatria, I.G.S., Patil, B.R., Samdup, T., Bebe, B.O., 2011. Impact of intensification of different types of livestock production in smallholder crop-livestock systems. Livestock Sci. 139, 22-29. 